\title{
A Comparison of the Efficacy of Nuclear Polyhedrosis and Granulosis Viruses in Spray and Bait Formulations for the Control of Agrotis segetum (Lepidoptera: Noctuidae) in Maize
}

\author{
TRACEY C. BOURNER, ${ }^{1}$ ENRIQUE VARGAS-OSUNA, ${ }^{2}$ \\ TREVOR WILLIAMS, ${ }^{1}$ CANDIDO SANTIAGO-ALVAREZ ${ }^{2}$ AND \\ JENNY S. CORY ${ }^{1}$
}

${ }^{\prime} N E R C$ Institute of Virology and Environmental Microbiology, Mansfield Road, Oxford, OXI 3SR, UK; ${ }^{2}$ Cátedra de Entomología Agrícola, Departamento de Ciencias y Recursos Agrícolas, ETSIA, Universidad de Córdoba, Apartado 3048, 14080 Córdoba, Spain

(Received for publication 20 July 1992)

\begin{abstract}
Agrotis segetum nuclear polyhedrosis virus (AsNPV) and granulosis virus (AsGV), propagated in laboratory cultures of A. segetum in England and A. ipsilon in Spain, respectively, were applied to plots of maize plants at the one-to four-leaf stage of growth. Plots were arranged in a $6 \times 6$ Latin square design and infested with second-instar A. segetum larvae (the common cutworm). Each virus was applied in separate treatments by two application methods; as an aqueous spray containing $0.1 \%$ Agral as a wetting agent, and as a bran bait. The NPV was applied at a rate of $4 \times 10^{12}$ polyhedra/ha, and the GV at $4 \times 10^{13}$ granules/ha. Soil and plants were sampled for larvae on three occasions following virus treatment: $24 h, 4$ days and 11 days. The larvae were reared on diet in the laboratory, until death or pupation, to examine the rate and level of viral infection. Infection data showed $87.5 \%$ and $91 \%$ NPV infection and $12.5 \%$ and $55 \% \mathrm{GV}$ infection in spray and bait treatments, respectively, in larvae sampled $24 \mathrm{~h}$ after treatment. In larvae sampled 4 days after treatment, the results were $78 \%$ and $100 \%$ NPV infection, and $13 \%$ and $6 \%$ GV infection. A total of only six larvae were retrieved on day 11 . In both treatments larvae infected with AsNPV died significantly more rapidly and at an earlier instar than those infected with AsGV, indicating that AsNPV appears to have better potential as a control agent for A. segetum.
\end{abstract}

Keywords: Agrotis segetum, Baculoviridae, biocontrol formulations, biological control, cutworm, granulosis virus, nuclear polyhedrosis virus.

\section{INTRODUCTION}

The larva of the turnip moth, Agrotis segetum (Denis \& Schiff.), is known as the common cutworm. The term cutworm is used to describe the behaviour of the larvae of a group of

Correspondence to Dr J. S. Cory. 
noctuid species which spend much of their time in the soil and sever the stems of seedlings or eat into root and tuber crops at or just below ground level. Cutworms can be very wasteful feeders, destroying far more plant material than they consume, and are very polyphagous, attacking a wide range of vegetable crops as well as wheat, maize, ornamentals and tree seedlings (Carter, 1984). A. segetum is distributed throughout the Palaearctic region from Europe to Japan, and is also found in parts of Africa, India and South East Asia (Cayrol, 1972). It is the most important cutworm pest in Europe (Carter, 1984).

Control of cutworms in Europe has for many years involved regular applications of organochlorine pesticides (Dunning, 1972; Zethner, 1977). However, adequate control of late instar cutworms is difficult to achieve, since at this stage the larvae spend most of their time below ground where they feed on untreated parts of the crop (Bowden et al., 1983). Since many crops affected by cutworms are intended for direct human consumption, safer alternatives to chemical pesticides are being sought (Zethner, 1980). One possibility is the use of baculoviruses, which have been used successfully against a wide range of agricultural and forest pests (Entwistle \& Evans, 1985). Particular examples of the commercial or operational use of baculoviruses against noctuid pests are given by Huber (1986). These include the following: 'Elcar', the NPV of Heliothis zea, which was registered for commercial use in the USA in 1975, and is effective against several species of Heliothis on cotton, maize, sorghum, soyabeans, tobacco and tomatoes; Spodoptera exigua NPV, distributed by extension workers in Thailand to more than 400 farms, and used very successfully; in China Heliothis armigera NPV has been produced and supplied locally to farming communities; in Columbia Trichoplusia ni NPV was used so successfully in cotton that it replaced all other control measures and $T$. ni ceased to be a pest in cotton. Yearian \& Young (1982) describe the use of Anticarsia gemmatalis NPV on soyabeans in North and South America, and consider this virus to be a strong candidate for commercial development.

Both nuclear polyhedrosis and granulosis viruses have been isolated from $A$. segetum (Lipa \& Ziemnicka, 1971; Lipa et al., 1971; Allaway \& Payne, 1983; Sherlock, 1983; Caballero et al. , 1989). Several authors have reported the successful use of $A$. segetum granulosis virus (AsGV) for the control of $A$. segetum and the closely related $A$. ipsilon in Pakistan (Shah et al., 1979), Denmark (Zethner, 1980) and Spain (Caballero et al., 1990, 1991) in tobacco, root crops and maize, respectively. AsGV is also registered as 'Virin-OS', a wettable powder, in the former Soviet Union for use against $A$. segetum in cotton (Lipa, 1991). However, no reports have been published on the use of $A$. segetum nuclear polyhedrosis virus (AsNPV) in the field.

Laboratory and greenhouse experiments (de Oliveira, 1988; de Oliveira \& Entwistle, 1990; Smith \& Cory, unpublished data; Bourner, unpublished data) have shown that AsNPV has considerable potential as a control agent for $A$. segetum. This trial was therefore designed to test AsNPV against a dose of AsGV previously found to give good control of third-instar A. segetum larvae in maize (Caballero et al., 1991) and to compare the effectiveness of each virus using different application methods.

\section{MATERIALS AND METHODS}

\section{Viruses}

The strain of AsGV used was isolated in Montilla, Spain, from field-collected A. segetum larvae and produced in bulk for the trial in larvae of $A$. ipsilon. Restriction endonuclease fragment profiles of the DNA of this isolate suggest that it is indistinguishable from that of the Danish AsGV isolate previously described (Allaway \& Payne, 1984; Vargas-Osuna, unpublished data).

The AsGV was extracted from macerated larval cadavers by filtering the homogenate through nylon mesh, and purified using sucrose density gradient centrifugation according to the method described by Griffith (1982). The purified virus was resuspended in water and stored at $4^{\circ} \mathrm{C}$. The concentration of GV inclusion bodies (IBs) was calculated from 10 independant counts 
using a counting chamber under a light microscope with dark-field illumination. The AsNPV originated from Rothamsted Experimental Station, Harpenden, Herts, UK. The virus was replicated in a laboratory culture of $A$. segetum larvae maintained on an artificial diet. In order to extract the ASNPV, infected larvae were macerated using a Stomacher Lab-Blender 80 (A. J. Seward, London) in $0.1 \%$ sodium dodecyl sulphate (SDS). The macerate was filtered through four layers of muslin, then centrifuged at $170 \times g$ for $5 \mathrm{~min}$ at $4^{\circ} \mathrm{C}$ to remove larval debris. The supernatant was spun twice at $13000 \times g$ for $30 \mathrm{~min}$ at $4^{\circ} \mathrm{C}$ to remove the SDS and to pellet the virus. The pellet was resuspended in deionized water, layered onto discontinuous sucrose gradients $(50-60 \%, w / w$, in water), and centrifuged at $70000 \times g$ for $90 \mathrm{~min}$ at $4^{\circ} \mathrm{C}$ using a swing-out rotor. The virus band was collected from the interface of the sucrose gradient and pelleted at $13000 \times g$ for $30 \mathrm{~min}$. The pellet was washed twice in deionized, filtered water. The concentration of polyhedral inclusion bodies (PIBs) was calculated using the dry counting method of Wigley (1980). In this method a suitable dilution of virus stock suspension was mixed with an equal volume of albumin $(10 \%, \mathrm{v} / \mathrm{v})$. Five microlitres of this suspension was spread evenly onto a $15 \mathrm{~mm}$ diameter circle on a microscope slide, four circles being prepared on each slide, with three replicates for each sample. The polyhedra were fixed at $80^{\circ} \mathrm{C}$ for $2 \mathrm{~min}$ on a hotplate, and stained in Buffalo black at $45^{\circ} \mathrm{C}$ for $5 \mathrm{~min}$. Using a light microscope with a $10 \times 10$ square eyepiece grid at $900 \times$ magnification, counts of polyhedra were made at 11 positions on one radius of each circle. The final concentration of polyhedra was calculated using a computer program which applies a weighting factor to each count.

\section{Field Site}

The site used was located at 'La Orden' experimental farm, Agricultural Research Service of Extremadura, Badajoz, Spain. The field was drilled with maize (Pioner 700) to give a $6 \times 6$ Latin square design. Each plot measured $2.25 \mathrm{~m} \times 2.4 \mathrm{~m}$, and contained three rows of maize, with 20 seeds sown per row. Plots were $2 \mathrm{~m}$ apart, separated by bare soil. The plants were watered by spray irrigation from each side of the field. Watering did not take place during the period from treatment of the plots until after the second sample had been taken, since this could have affected the virus treatments. The site had not previously been used for any trials involving baculoviruses.

\section{Insects}

Each plant was infested at the one- to four-leaf stage with three second-instar $A$. segetum larvae. The larvae were from the eighth generation of a stock colony maintained at the Agricultural Entomology laboratory of the University of Cordoba, originating from fieldcollected larvae. Infestation took place early in the day and viral treatments were applied in the evening of the same day to avoid high levels of ultraviolet radiation.

\section{Treatments}

There were six treatments: two of AsNPV, two of AsGV, and two infested controls, one for each method of application. Each treatment was replicated six times in a Latin square design. Each virus was applied by two application methods, consisting of a spray and a bait formulation. AsNPV was applied at a rate of $4 \times 10^{12}$ polyhedra/ha and AsGV at $4 \times 10^{13}$ granules/ha. The doses were the same for both spray and bait treatments and were chosen from experience with previous trials (Caballero et al., 1990, 1991; Bourner, unpublished data). The virus treatments were carried out on 27 May 1991.

The spray treatments were applied using 'Matabi Kima-6' 6-1 pressurized barrel sprayers (TUV, Rheinland, Köln, Germany), which allowed accurate distribution of the spray with minimum drift. The spray was applied evenly along each row of plants from a height of approximately $40 \mathrm{~cm}$. Each virus was applied using a clean sprayer to avoid cross-contamination. Each treatment consisted of 1.51 of aqueous suspension containing $0.1 \%$ Agral as a wetting agent. equivalent to $463 \mathrm{l} / \mathrm{ha}$. Control plots were spraved with $0.1 \%$ aqueous Agral only. 
Bait treatments were applied manually. For each treatment, 1.51 of aqueous suspension of virus was mixed with $800 \mathrm{~g}$ of wheat bran, which was placed on the soil along the rows of maize. The application rate was equivalent to $710 \mathrm{~kg} / \mathrm{ha}$ of bait. Control plots were treated with bran mixed with water only.

\section{Larval Sampling}

Samples of $A$. segetum larvae were retrieved from the plots on three occasions: $24 \mathrm{~h}, 4$ days and 11 days after treatment, in order to compare levels of infection between viruses and application methods, and to examine the possibility of secondary infection of larvae, i.e. acquisition of virus by previously healthy larvae from diseased larvae.

On each sampling date, $10 \%$ of the plants were removed from each plot, along with the soil from around their roots to a depth of $3 \mathrm{~cm}$ and a diameter of approximately $10 \mathrm{~cm}$. Larvae were removed from the soil in the laboratory using soil sieves and reared individually in ventilated plastic pots containing artificial diet (Poitout $\&$ Bues, 1974) at a temperature of $26^{\circ} \mathrm{C} \pm 2{ }^{\circ} \mathrm{C}$, until death or pupation. For each larva, the time to death was recorded as the mid-point between the time when it was found to be dead and the time when it was previously checked, i.e. a larva alive on day 8 and dead on day 9 was assigned a time to death of 8.5 days.

\section{Larval Diagnosis}

Diagnosis of viral deaths was performed visually since the symptoms of viral infection are easily observed. Both viruses cause the body contents to turn into a milky fluid and infected larvae appear swollen. However, each virus produces slightly different symptoms, which enable them to be distinguished visually. In AsNPV infections the larval integument usually remains intact, but is easily broken when touched, releasing polyhedra. The larvae develop a pinkish tinge and frass production usually ceases soon after the appearance of symptoms. In AsGV infections the integument becomes very weak and often ruptures without being touched. The larvae appear whiter than normal, turning grey soon after death, when the integument almost always breaks down. The symptomatic period is longer than for AsNPV infection, and frass production continues after the appearance of symptoms. A few larvae $(6 \%$ of the total retrieved from the day 1 samples) died without producing any of the above symptoms. These larvae were excluded from all analyses, as were the small number of larvae from the two later samples which were found to be parasitized by hymenopteran parasitoids. The instar of each larva was recorded at death.

\section{Damage Assessment}

Every plant was examined for cutworm damage on each sampling date, with a final assessment being made on 21 June 1991, 2 weeks after the last larval sample.

\section{Statistical Analysis}

The number of larvae retrieved from each plot on each sampling date was examined using an analysis of variance. As larval numbers decreased rapidly in the two later samples (4 and 11 days post-treatment) detailed statistical analysis was only carried out on the $24 \mathrm{~h}$ (day 1) collection of larvae.

The virus mortality of larvae from the day 1 samples was analysed by fitting generalized linear models assuming a binomial error distribution, using a GLIM program (Royal Statistical Society, 1985). Treatment means from the models were compared using $t$-tests. Changes in the model deviance resulting from the inclusion or removal of the relevant variables, such as row, column or formulation effects, were assessed using chi-squared statistics.

The time to death of each virus-infected larva from the day 1 samples was recorded, and a mean value for each treatment calculated. An analysis of variance was also performed using the mean time to death of larvae from each plot, and means calculated for each virus by this method were compared using $t$-tests. 
The instar distribution of virus-killed larvae from the day 1 sample was compared for each treatment using chi-squared tests.

\section{RESULTS}

The total and mean number of larvae recovered from the treatments on each sampling date are shown in Table 1. A good level of larval recovery was attained on day 1 ( $24 \mathrm{~h}$ after treatment), but this dropped off rapidly during the sampling period, resulting in poor recovery on day 11 , by which time the larvae had reached the third or fourth instar. There were no significant differences between the number of larvae retrieved from each treatment on any of the three sampling dates (day $1, F=0.70$, df $=5,20, P=0.63$; day $4, F=0.76$, df $=5,20, P=0.59$; day $11, F=1.23$, df $=5,20, P=0.33$ ).

The larvae ingested a lethal dose of AsNPV or AsGV very soon after treatment, as can be seen from the mortality observed in the larvae sampled from the field on day 1 . The final virus mortality of the larvae retrieved on days 1 and 4 is shown in Table 2. The data from

TABLE 1. Number of Agrotis segetum larvae retrieved from each treatment (six plots) on each of three sampling dates after virus application

\begin{tabular}{|c|c|c|c|c|}
\hline Treatment & $\begin{array}{l}\text { Days post } \\
\text { application }\end{array}$ & $\begin{array}{l}\text { Total per } \\
\text { treatment }\end{array}$ & $\begin{array}{l}\text { Mean per } \\
\text { plot }\end{array}$ & $\begin{array}{l}\text { Standard } \\
\text { error }\end{array}$ \\
\hline Control (spray) & $\begin{array}{r}1 \\
4 \\
11\end{array}$ & $\begin{array}{r}26 \\
8 \\
1\end{array}$ & $\begin{array}{l}4.33 \\
1.33 \\
0.16\end{array}$ & $\begin{array}{l}0.71 \\
0.49 \\
0.17\end{array}$ \\
\hline Control (bait) & $\begin{array}{r}1 \\
4 \\
11\end{array}$ & $\begin{array}{r}22 \\
12 \\
2\end{array}$ & $\begin{array}{l}3.67 \\
2.00 \\
0.33\end{array}$ & $\begin{array}{l}0.95 \\
1.13 \\
0.33\end{array}$ \\
\hline AsNPV spray & $\begin{array}{r}1 \\
4 \\
11\end{array}$ & $\begin{array}{r}24 \\
9 \\
0\end{array}$ & $\begin{array}{l}4.00 \\
1.50 \\
0.00\end{array}$ & $\begin{array}{l}1.32 \\
0.43 \\
0.00\end{array}$ \\
\hline AsNPV bait & $\begin{array}{r}1 \\
4 \\
11\end{array}$ & $\begin{array}{r}25 \\
8 \\
0\end{array}$ & $\begin{array}{l}4.17 \\
1.33 \\
0.00\end{array}$ & $\begin{array}{l}1.28 \\
0.33 \\
0.00\end{array}$ \\
\hline AsGV spray & $\begin{array}{r}1 \\
4 \\
11\end{array}$ & $\begin{array}{r}25 \\
12 \\
0\end{array}$ & $\begin{array}{l}4.17 \\
2.00 \\
0.00\end{array}$ & $\begin{array}{l}0.75 \\
0.93 \\
0.00\end{array}$ \\
\hline AsGV bait & $\begin{array}{r}1 \\
4 \\
11\end{array}$ & $\begin{array}{r}38 \\
17 \\
3\end{array}$ & $\begin{array}{l}6.33 \\
2.83 \\
0.50\end{array}$ & $\begin{array}{l}1.09 \\
0.79 \\
0.22\end{array}$ \\
\hline
\end{tabular}

TABLE 2. Percentage viral mortality of Agrotis segetum larvae samples collected on days 1 and 4 after treatment. Standard errors were calculated assuming a binomial distribution (standard error $=[\mathrm{pq} / n]^{-2}$ )

\begin{tabular}{|c|c|c|c|c|c|}
\hline \multirow[b]{2}{*}{ Treatment } & \multicolumn{2}{|c|}{ Day } & \multirow[b]{2}{*}{$\begin{array}{l}\text { Mortality } \\
(\%)\end{array}$} & \multirow[t]{2}{*}{ Day 4} & \multirow[b]{2}{*}{$\begin{array}{c}\text { Standard } \\
\text { error }\end{array}$} \\
\hline & $\begin{array}{c}\text { Mortality } \\
\text { (\%) }\end{array}$ & $\begin{array}{l}\text { Standard } \\
\text { error }\end{array}$ & & & \\
\hline AsNPV spray & 87.5 & \pm 6.75 & 77.8 & & \pm 13.86 \\
\hline AsNPV bait & 91.3 & \pm 5.88 & 100 & & - \\
\hline AsGV spray & 12.5 & \pm 6.75 & 12.5 & & \pm 11.69 \\
\hline AsGV bait & 54.8 & \pm 8.94 & 6.3 & & \pm 6.05 \\
\hline
\end{tabular}


the day 1 samples agreed almost exactly with a binomial distribution (scaling factor $=0.98$ ). Low numbers of larvae retrieved on day 4 make most statistical comparisons impossible, but overall AsNPV mortality $(\mathbf{8 8 . 2 \% )}$ was significantly higher than the level achieved by AsGV $(8.3 \%)(t=2.633, \mathrm{df}=17, P<0.02)$. As might be expected, the level of mortality reached on both sampling dates was similar for the NPV. However, the level of mortality for the GV bait treatment was surprisingly low on the second sampling date, but again the small numbers of larvae prevent meaningful comparison with the day 1 data.

The data for the cumulative virus mortality of day 1 samples are shown in Figures 1 and 2 , and as can be seen, in both spray and bait formulations AsNPV reached a higher level of mortality than AsGV. A significant amount of variation in the virus mortality of larvae sampled on day 1 was explained by the virus treatments $\left(\chi^{2}=37.73, \mathrm{df}=1, P<0.001\right)$ and the formulations $\left(\chi^{2}=4.45\right.$, df $=1, P<0.05$ ) (Table 3 ). Virus and formulation

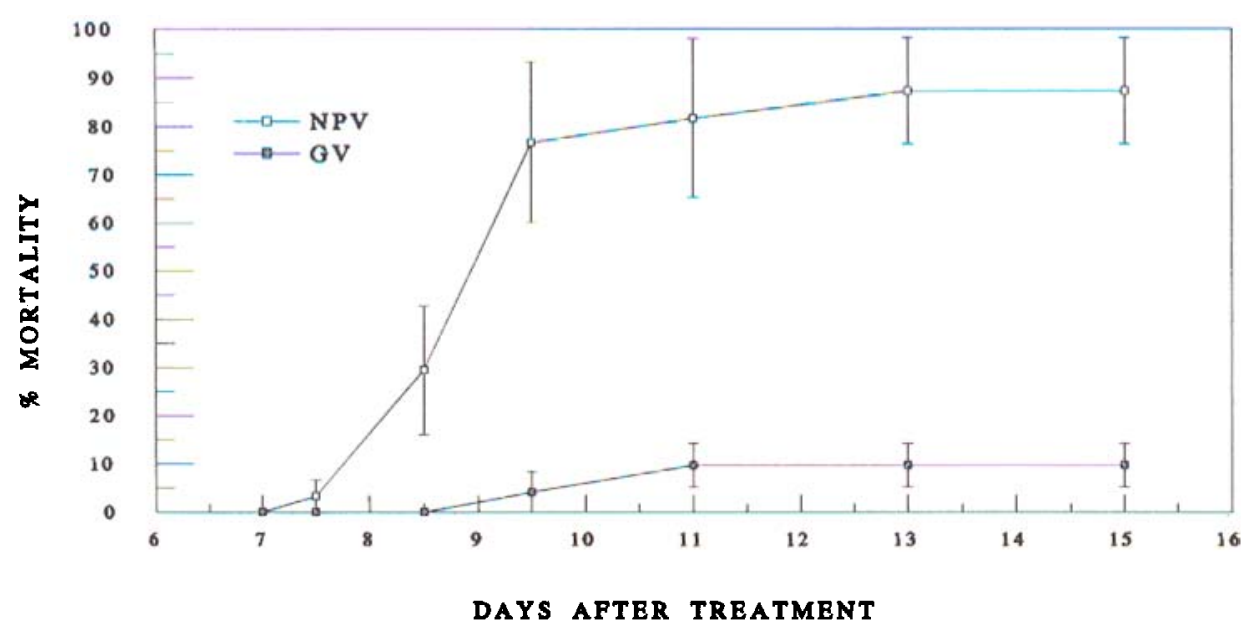

FIGURE 1. Cumulative percentage mortality ( \pm standard errors) of $A$. segetum larvae dying of viral infection after spray treatment. Larvae were collected 1 day after treatment and reared in the laboratory.

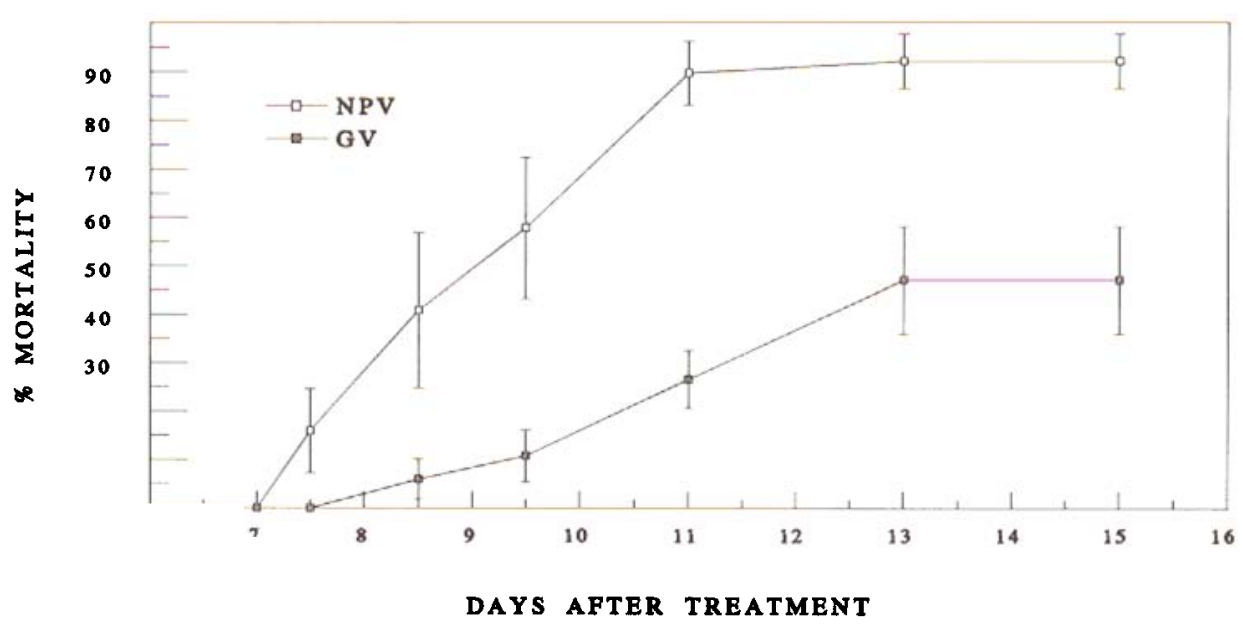

FIGURE 2. Cumulative percentage mortality ( \pm standard errors) of $A$. segetum larvae dying of viral infection after hait treatment $I$ arvae were collected 1 dav after treatment and reared in the lahnratnry 
TABLE 3. GLIM analysis of virus mortality data from Agrotis segetum larvae collected 1 day after treatment

\begin{tabular}{lccccc}
\hline Source & $\begin{array}{c}\text { Residual } \\
\text { deviance }\end{array}$ & df & $\begin{array}{c}\text { Change in } \\
\text { deviance }\end{array}$ & df & $\begin{array}{c}\text { Significance } \\
\left(\chi^{2}\right)\end{array}$ \\
\cline { 2 - 3 } & 62.73 & 23 & - & - & - \\
$\quad$ Columns & 60.71 & 22 & 0.06 & 1 & NS \\
Rows & 22.98 & 20 & 1.96 & 1 & NS \\
Virus $(v)$ & 18.53 & 19 & 47.73 & 1 & $P<0.001^{* * *}$ \\
Formulation $(f)$ & 16.53 & 18 & 2.00 & 1 & $P<0.05^{*}$ \\
Interaction $(v \times f)$ & & & 1 & NS \\
\hline
\end{tabular}

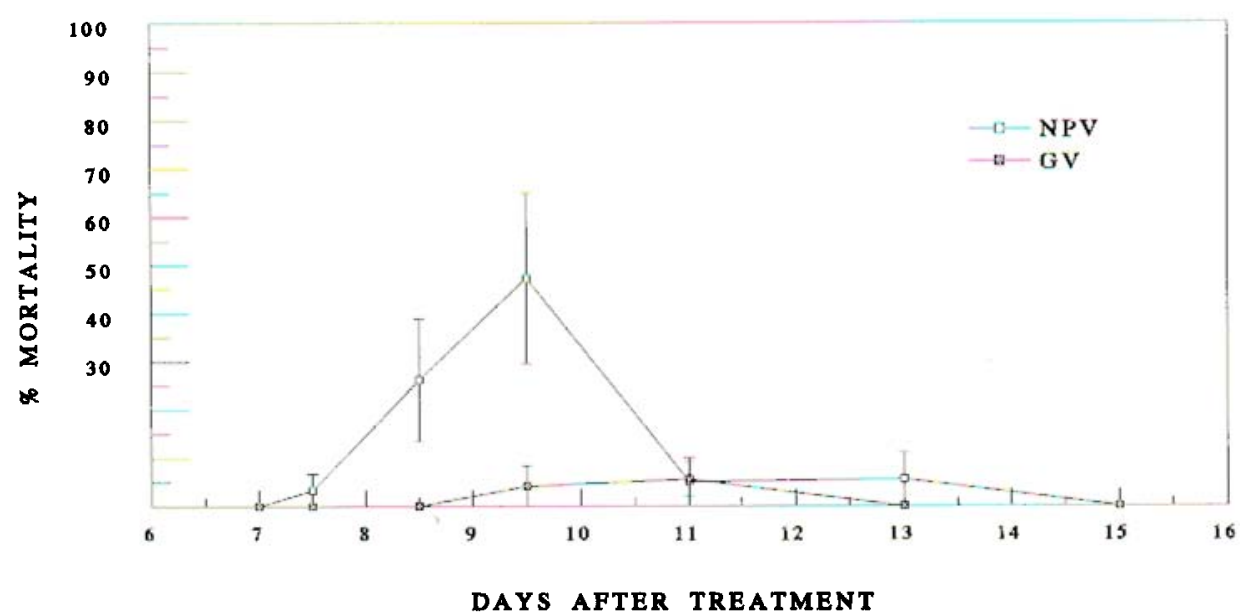

FIGURE 3. Percentage of $A$. segetum larvae ( \pm standard errors) dying of viral infection after spray treatment. Larvae were collected 1 day after treatment and reared in the laboratory.

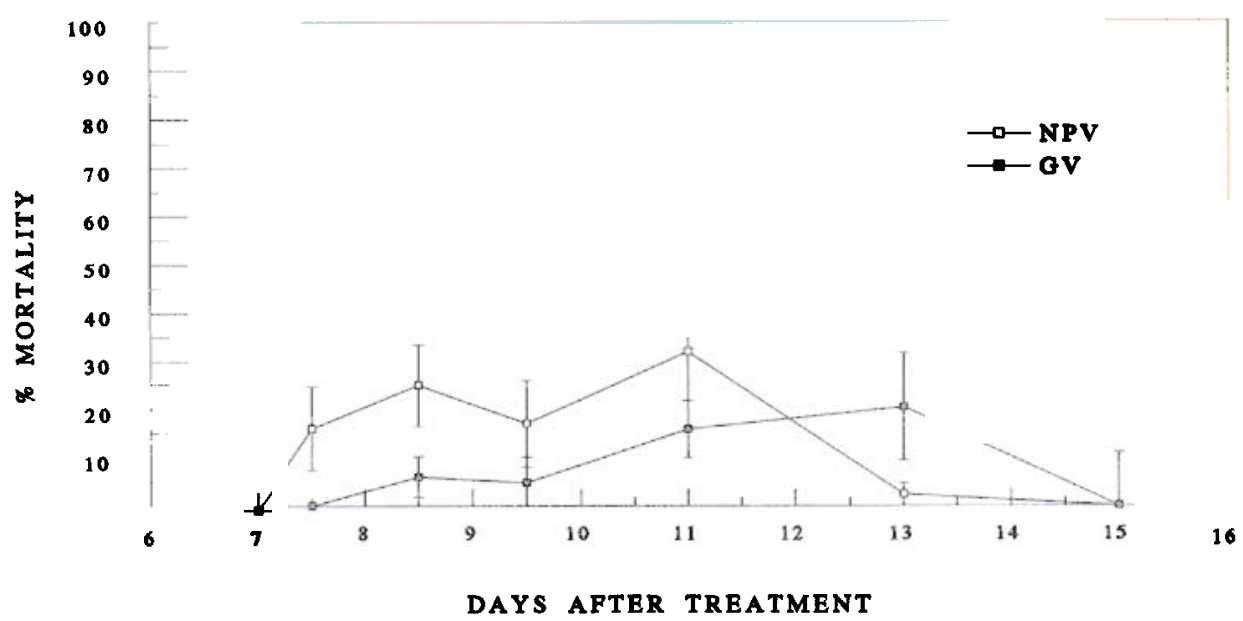

FIGURE 4. Percentage of $A$. segetum larvae ( \pm standard errors) dying of viral infection after bait treatment. Larvae were collected 1 day after treatment and reared in the laboratory. 
means and their standard errors were: NPV $89.36 \% \pm 4.5$; GV $36.36 \% \pm 6.5$; spray $50.00 \%$ \pm 7.2 ; bait $70.37 \% \pm 6.2$. No other significant effects were found. The level of mortality achieved by the NPV was similar for both formulations $(t=0.282, \mathrm{df}=10, P>0.1)$. Although the AsGV bait treatment appeared to perform better than the GV spray the difference was not significant $(t=1.664$, df $=10, P>0.1$ ). Overall, NPV mortality was significantly higher than GV mortality $(t=2.726$, df $=22, P<0.02)$.

The control plots were excluded from the viral mortality analyses since only one viral death was observed in the bait treatment out of 22 larvae retrieved, and none occurred in the spray treatment out of 26 larvae retrieved. This indicates that background levels of virus or movement of virus between the plots were negligible.

If virus mortality data from the day 1 samples are considered in terms of the number of larvae which died on each day following treatment, it becomes evident that peak larval mortality occurred approximately 2 days earlier in AsNPV treatments than in AsGV treatments (Figures 3 and 4). Similarly, the slopes of the cumulative mortality curves in Figures 1 and 2 are steeper for NPV than for GV treatments. Table 4 gives the mean time to death for larvae from each treatment, combining all plots for each treatment. The mean times to death calculated from the analysis of variance, which takes into account the plot layout, were 9.63 days for AsNPV and 10.99 days for AsGV. These were significantly different $(F=6.28, \mathrm{df}=18$, $P=0.022$ ). This trend is also reflected in the instar in which the larvae died (Table 5). The majority of larvae in the NPV treatments died in the third instar, whereas those from the GV treatments were spread over the third, fourth and even the fifth instar. Chi-squared tests performed on these data showed that the NPV bait treatment gave a significantly different result to the GV bait $\left(\chi^{2}=9.51\right.$, df $\left.=2, P<0.01\right)$. Spray treatments could not be compared directly because of the low mortality in the GV treatment. The NPV spray treatment was not significantly different to the NPV bait $\left(\chi^{2}=2.12\right.$, df $\left.=2, P>0.1\right)$. Disregarding formulation, the difference between NPV and GV treatments was highly significant $\left(\chi^{2}=16.34\right.$, df $\left.=2, P<0.001\right)$.

The level of damage to the maize plants was low in all treatments ( $<22 \%$ mortality). Additionally, some plants disappeared between sampling dates, and it was not possible to say whether death had been due to cutworm damage or dehydration, so detailed statistical analysis of the damage data was not attempted.

TABLE 4. Mean time to death of virus-killed A. segetum larvae collected 1 day after treatment (all plots combined for each treatment)

\begin{tabular}{lcc} 
Treatment & $\begin{array}{c}\text { Mean time to } \\
\text { death (days) }\end{array}$ & Standard error \\
\hline NPV spray & & \pm 0.286 \\
NPV bait & 9.31 & \pm 0.317 \\
GV spray & 9.40 & \pm 0.500 \\
GV bait & 10.50 & \pm 0.397
\end{tabular}

TABLE 5. Instar of virus-killed $A$. segetum larvae at death for NPV and GV treatments (larvae sampled one day after treatment)

Instar at death

\begin{tabular}{lcccc} 
Treatment & Second & Third & Fourth & Fifth \\
\cline { 2 - 5 } NPV spray & 2 & 16 & 3 & \\
NPV bait & 0 & 18 & 3 & \\
GV spray & 0 & 1 & 2 & 0 \\
GV bait & & 6 & 6 & 4 \\
\hline
\end{tabular}


Parasitoids were only obtained from larvae in the day 4 samples. The two species present were identified as Campoletis anulata (Hymenoptera: Ichneumonidae) and Apanteles telengai (Hymenoptera: Braconidae). Five larvae were parasitized by the former, and one (in the GV spray treatment) by the latter. All parasitoids emerged from fourth- or fifth-instar larvae, 12 to 14 days after treatment. Although the numbers involved were too low to be statistically relevant, it was noted that parasitism occurred in both control and GV treated plots, but not in NPV treatments.

\section{DISCUSSION}

At the doses used (AsNPV $4 \times 10^{12}$ polyhedra/ha, AsGV $4 \times 10^{13}$ granules/ha), it is clear that AsNPV caused higher and more rapid mortality than AsGV when applied against second instar $A$. segetum larvae, in both spray and bait formulations. In the day 1 samples, the difference between the spray treatments was very marked $(87.5 \%$ for AsNPV compared with $12.5 \%$ mortality for AsGV), with both bait treatments giving higher (but not significantly so) mortalities (91.3\% for AsNPV compared with $54.8 \%$ for AsGV). It is also evident from these results that the larvae were ingesting a lethal dose of virus in $24 \mathrm{~h}$. In the day 4 samples the relationships were similar (spray $77.8 \%$ [NPV] and $12.5 \%$ [GV], bait $100 \%$ [NPV] and $6.3 \%$ [GV]), except for the large drop in GV bait activity for which there is no obvious explanation. The bait formulation appears to be at least as effective in terms of larval mortality as the spray. More work is required to study the cost-effectiveness of each formulation, and to determine whether significant ultraviolet protection is achieved using a bait. In this study the quantity of bait used was very high, but was chosen to allow comparison with previous trials (Caballero et al., 1990, 1991). Future studies will aim to reduce the application rate.

Too few larvae were recovered in the later (day 11) sample to allow detection of secondary infection, although as the active lifetime of the bait is not known, it may not have been possible to distinguish between larvae which had acquired a lethal dose from earlier-infected larvae and those acquiring a late dose from the original inoculum in the bait-treated plots. The effect of a longer-lived inoculum on the distribution of viral deaths with time will be further investigated.

Direct comparisons between the baculoviruses in terms of numbers of occlusion bodies are difficult because of the different morphologies of the two viruses. AsNPV is a multiply enveloped virus; that is, one polyhedron contains approximately 700 infective units (Allaway, 1983), whereas AsGV, like other GVs, consists of a single infective unit contained in each granule. However, a simple dose ratio based on the relative number of infective units would not provide an accurate comparison of efficacy either, since one NPV polyhedron can only infect one larva, whereas $700 \mathrm{GV}$ granules can, in theory, infect 700 larvae. The use of 'larval equivalents' as a means of comparing doses can be used, but care must be taken to standardize dosing methods, rearing conditions, harvesting procedures and virus extraction to obtain comparable results (Shapiro, 1982). $\mathrm{LD}_{50}$ values for AsNPV and AsGV in second-instar. A. segetum larvae of 700 polyhedra and 4000 granules, respectively, have been obtained from standardized diet plug assays (Bourner, unpublished data) giving a GV to NPV ratio of 5.7 occlusion bodies. However, in this trial the GV to NPV dose ratio was 10, but GV mortality was lower than NPV mortality. Differences in response to environmental effects such as ultraviolet degradation, and leaf, soil or bait $\mathrm{pH}$ mean that field efficacy may not reflect laboratory $\mathrm{LD}_{50}$ values.

The slower activity of AsGV seen in the trial reflects results obtained in the laboratory using a series of AsGV doses (Bourner, unpublished data) and results obtained in other $\mathrm{LT}_{50}$ studies (Allaway \& Payne, 1984), and is probably a genuine characteristic of the virus rather than a function of the doses used. After sampling, the GV-infected larvae continued to feed on semi-synthetic diet in the laboratory after NPV-infected larvae from the same sample had died. Since $A$. segetum larvae cause minor damage, mostly to foliage, in the first and second instars, but more severe damage to the base of the plants from the third instar onwards, a 
control agent causing death as early as possible is desirable. This is especially true in the case of high-value crops such as vegetables which need to be marketed blemish-free. From the distribution of the instars of infected larvae at death it is clear that the GV not only killed larvae more slowly than the NPV, but also allowed a significant proportion of infected larvae to undergo one, or even two, further moults. Therefore, even at equivalent levels of infection, the GV may allow $A$. segetum larvae to cause a significant amount of damage before dying.

Earlier field trials against Agrotis species (Shah et al., 1979; Zethner, 1980; Zethner et al. 1987; Caballero et al., 1990, 1991) used only AsGV, and all except the latter two used only spray formulations. Trials using AsGV against second-instar larvae of the closely related species $A$. ipsilon in Pakistan obtained up to $78 \%$ damage reduction using a dose of $3 \times 10^{13}$ granules/ha on tobacco seedlings (Shah et al., 1979). Two applications of $2 \times 10^{13}$ granules/ha on sugar beet against naturally occurring $A$. ipsilon larvae of unspecified instar gave $63 \%$ damage reduction (Zethner et al., 1987). These dosages appear low when it is considered that the $\mathrm{LD}_{50}$ of AsGV in third-instar $A$. ipsilon larvae has been reported as being a factor of $5 \times 10^{3}$ greater than in third-instar $A$. segetum larvae (Caballero et al., 1988), although another, much smaller, study found that the response of second-instar $A$. ipsilon and $A$. segetum larvae to AsGV was similar (Zethner \& Ogaard, 1982). This difference, however, may be attributable to varying susceptibilities of different populations of larvae.

Field trials using spray formulations of AsGV against first-instar $A$. segetum larvae were reported as producing only $50 \%$ damage reduction in root crops at $5 \times 10^{11}$ granules $/$ ha, but good control (approximately $75 \%$ damage reduction) at either $5 \times 10^{12}$ or $5 \times 10^{13}$ granules/ha (Zethner, 1980). In the previous spray trials in Spain using maize, $4 \times 10^{12}$ granules/ha against first-instar larvae did not reduce damage compared to control plots (Caballero et al., 1990, 1991), but in these trials damage levels in the controls were very low. Bait formulations of AsGV against third instar A. segetum in maize gave up to $50 \%$ damage reduction at $4 \times 10^{12}$ granules/ha and up to $60 \%$ at $4 \times 10^{13}$ granules/ha (Caballero et al., 1990, 1991).

None of the previous baculovirus trials with Agrotis species monitored virus uptake by sampling larvae at intervals after treatment, and all relied solely on damage assessment to determine the effectiveness of virus applications. In this trial, the importance of using more than one method of assessment became clear because of the difficulties associated with diagnosing the causes of plant death. Damage levels were low in all treatments. This was considered to be due to the nature of the crop used and the instar of the larvae at the time of infestation in relation to the stage of growth of the plants. In earlier trials, GV bait-treated plots were infested with third-instar $A$. segetum larvae and the control plots were heavily damaged (Caballero et al., 1990, 1991). Since maize plants are quite resistant to cutworm attack beyond the five-leaf stage due to the toughness of the stem, their window of susceptibility to this pest is quite narrow. Due to uneven irrigation of the field the plants differed in size between plots. Therefore, the stage of development of the maize plants at the time of infestation of the plots is likely to have influenced their chances of survival: larger plants being more resistant to cutworm attack (and dehydration) than smaller ones. For this reason the use of a crop with a longer window of susceptibility to cutworm attack would make future trials more sensitive in assessing treatment efficacy.

It is apparent from the larval infection data that AsNPV appears to be a more suitable control agent for $A$. segetum in the field than AsGV due to its more rapid action. As a preliminary trial, the results of this study indicate that baculoviruses have potential for control of an important group of pests. Cutworms are sporadic, polyphagous and attack high-value crops destined for human consumption in which chemical pesticide residues are increasingly being recognized as a problem, making baculoviruses a particularly valuable option. Further trials should be carried out to optimize dose levels and application methods in different crop systems to evaluate the cost-effectiveness of baculoviruses in comparison with chemical methods of cutworm control. 
control agent causing death as early as possible is desirable. This is especially true in the case of high-value crops such as vegetables which need to be marketed blemish-free. From the distribution of the instars of infected larvae at death it is clear that the GV not only killed larvae more slowly than the NPV, but also allowed a significant proportion of infected larvae to undergo one, or even two, further moults. Therefore, even at equivalent levels of infection, the GV may allow $A$. segetum larvae to cause a significant amount of damage before dying.

Earlier field trials against Agrotis species (Shah et al., 1979; Zethner, 1980; Zethner et al. 1987; Caballero et al., 1990, 1991) used only AsGV, and all except the latter two used only spray formulations. Trials using AsGV against second-instar larvae of the closely related species $A$. ipsilon in Pakistan obtained up to $78 \%$ damage reduction using a dose of $3 \times 10^{13}$ granules/ha on tobacco seedlings (Shah et al., 1979). Two applications of $2 \times 10^{13}$ granules/ha on sugar beet against naturally occurring $A$. ipsilon larvae of unspecified instar gave $63 \%$ damage reduction (Zethner et al., 1987). These dosages appear low when it is considered that the $\mathrm{LD}_{50}$ of AsGV in third-instar $A$. ipsilon larvae has been reported as being a factor of $5 \times 10^{3}$ greater than in third-instar $A$. segetum larvae (Caballero et al., 1988), although another, much smaller, study found that the response of second-instar $A$. ipsilon and $A$. segetum larvae to AsGV was similar (Zethner \& Ogaard, 1982). This difference, however, may be attributable to varying susceptibilities of different populations of larvae.

Field trials using spray formulations of AsGV against first-instar $A$. segetum larvae were reported as producing only $50 \%$ damage reduction in root crops at $5 \times 10^{11}$ granules $/$ ha, but good control (approximately 75\% damage reduction) at either $5 \times 10^{12}$ or $5 \times 10^{13}$ granules/ha (Zethner, 1980). In the previous spray trials in Spain using maize, $4 \times 10^{12}$ granules/ha against first-instar larvae did not reduce damage compared to control plots (Caballero et al., 1990, 1991), but in these trials damage levels in the controls were very low. Bait formulations of AsGV against third instar $A$. segetum in maize gave up to $50 \%$ damage reduction at $4 \times 10^{12}$ granules/ha and up to $60 \%$ at $4 \times 10^{13}$ granules/ha (Caballero et al., 1990, 1991).

None of the previous baculovirus trials with Agrotis species monitored virus uptake by sampling larvae at intervals after treatment, and all relied solely on damage assessment to determine the effectiveness of virus applications. In this trial, the importance of using more than one method of assessment became clear because of the difficulties associated with diagnosing the causes of plant death. Damage levels were low in all treatments. This was considered to be due to the nature of the crop used and the instar of the larvae at the time of infestation in relation to the stage of growth of the plants. In earlier trials, GV bait-treated plots were infested with third-instar $A$. segetum larvae and the control plots were heavily damaged (Caballero et al., 1990, 1991). Since maize plants are quite resistant to cutworm attack beyond the five-leaf stage due to the toughness of the stem, their window of susceptibility to this pest is quite narrow. Due to uneven irrigation of the field the plants differed in size between plots. Therefore, the stage of development of the maize plants at the time of infestation of the plots is likely to have influenced their chances of survival: larger plants being more resistant to cutworm attack (and dehydration) than smaller ones. For this reason the use of a crop with a longer window of susceptibility to cutworm attack would make future trials more sensitive in assessing treatment efficacy.

It is apparent from the larval infection data that AsNPV appears to be a more suitable control agent for $A$. segetum in the field than AsGV due to its more rapid action. As a preliminary trial, the results of this study indicate that baculoviruses have potential for control of an important group of pests. Cutworms are sporadic, polyphagous and attack high-value crops destined for human consumption in which chemical pesticide residues are increasingly being recognized as a problem, making baculoviruses a particularly valuable option. Further trials should be carried out to optimize dose levels and application methods in different crop systems to evaluate the cost-effectiveness of baculoviruses in comparison with chemical methods of cutworm control. 


\section{ACKNOWLEDGEMENTS}

This work was funded by the British Council and the Spanish Ministerio de Education y Ciencia through the Acciones Integradas programme.

We are very grateful to Ann Cleverly of Wellcome Environmental Health, Berkhamsted UK, and John Fenlon of Horticulture Research International, Littlehampton, UK, for their assistance with the statistical analysis of the data. Thanks also to Chris Prior of IIBC, Ascot, UK for his interest in this work.

\section{REFERENCES}

ALLAWAY, G.P. (1983) Virus particle packaging in baculovirus and cytoplasmic polyhedrosis virus inclusion bodies. Journal of Invertebrate Pathology 42, 357-368.

Allaway, G.P. \& PAYNE, C.C. (1983) A biochemical and biological comparison of three European isolates of nuclear polyhedrosis viruses from Agrotis segetum. Archives of Virology 75, 43-54.

Allaway, G. P. \& Payne, C.C. (1984) Host range and virulence of five baculoviruses from lepidopterous hosts. Annals of Applied Biology 105, 29-37.

Bowden, J., Cochrane, J., Emmett, B.J., Minall, T.E. \& Sherlock, P.L. (1983) A survey of cutworm attacks in England and Wales, and a descriptive population model for Agrotis segetum (Lepidoptera: Noctuidae). Annals of Applied Biology 102, 29-47.

Caballero, P., Fleishacker, C., Vargas-Osuna, E. \& Santiago-Alvarez, C. (1988) Un baculovirus autoctono (virus de la granulosis; VG) de Agrotis segetum Lepidoptera: Noctuidae) y sus posibilidades de empleo en la lucha contra "gusanos grises". Boletin de Sanidad Vegetal Plagas 14, 171-174.

Caballero, P., Vargas-Osuna, E. \& Santiago-Alvarez, C. (1989) Presencia de "gusanos grises" sobre diversos cultivos en Andalucía y Extremadura y sus parásitos y patógenos asociados. Boletin de Sanidad Vegetal Plagas 15, 3-7.

Caballero, P., Vargas-Osuna, E. \& Santiago-Alvarez, C. (1990) Aplicación en campo del Virus de la Granulosis de Agrotis segetum Schiff. (Lepidoptera: Noctuidae). Boletin de Sanidad Vegetal Plagas 16, 333-337.

Caballero, P., Vargas-Osuna, E. \& Santiago-Alvarez, C. (1991) Efficacy of a Spanish strain of Argrotis segetum granulosis virus (Baculoviridae) against Agrotis segetum Schiff. (Lep.: Noctuidae) on corn. Journal of Applied Entomology 112, 59-64.

CARTER, D.J. (1984) Pest Lepidoptera of Europe with Special Reference to the British Isles. Dr W. Junk Publishers, Dordrecht. pp. 431.

Cayrol, R.A. (1972) Famille des noctuides, in Entomologie Appliqué á l'Agriculture, T. II, Vol. 2, Lepidoptéres (Balachowsky, A.S., Ed.) Masson et Cie, Paris, pp. 1255-1614.

DunNing, R.A. (1972) Sugar beet pest and disease incidence and damage, and pesticide usage. Report of an IIRB enquiry. IIRB Revue de l'Institut International de Recherches Betteravieres (Belgium). 6, 19-34.

Entwistle, P.F. \& Evans,H.F. (1985) Viral Control, in Comprehensive Insect Physiology, Biochemistry and Pharmacology, (Kerkut, G.A. \& Gilbert, L.I., (Eds), Vol. 12. Pergamon Press, Oxford, pp. 347-412.

GrIFFITH, I.P. (1982) A new approach to the problem of identifying baculoviruses, in Microbial and Viral Pesticides, (KurSTAK, E., Ed.), Marcel Dekker, New York, pp. 507-531.

Huber, J. (1986) Use of baculoviruses in pest management programs, in The Biology of Baculoviruses, Vol. 2 Practical Application for Insect Control (Granados, R.R. \& FedericI, B.A., Eds), CRC Press, Florida, pp. 181 - 202.

LIPA, J.J. (1991) Microbial pesticides and their use in EPRS-IOBC region (Eastern Europe). IOBC/WPRS Bulletin 14, 23-32.

LIPA, J.J. \& ZIEMNICKA, J. (1971) Studies on the granulosis virus of cutworms Agrotis spp. (Lepidoptera, Noctuidae). Acta Microbiologica Polonica Ser. B, 3(20), No. 3: 155-162.

LiPA, J.J., Ziemnicka, J. \& GudZ-GoRBan, A.P. (1971) Electron microscopy of nuclear polyhedrosis virus from Agrotis segetum Schiff. and A. exclamationis L. (Lepidoptera, Noctuidae). Acta Microbiologica Polonica Ser. $B$ 3(20), No. 1: 55-61.

OliveIRA, M.R.V. DE (1988) The ecology of Agrotis segetum, turnip moth (Lepidoptera: Noctuidae) nuclear polyhedrosis virus and its use as a control agent. Unpublished Master of Science Thesis, University of Oxford.

Oliveira, M.R.V. De \& ENTwistle, P.F. (1990) Agrotis segetum (Schiff.) (Lepidoptera: Noctuidae) and assessment of plant damage. Proceedings and Abstracts, Fifth International Colloquium on Invertebrate Pathology and Microbial Control, Adelaide, Society for Invertebrate Pathology, USA, p. 493.

Poitout, S. \& Bues, R. (1974) Elevage des chenilles de vingt-huit espèces de lépidoptères Noctuidae et de deux espèces d'Arctiidae sur milieu artificiel simple. Particularités de l'élevage selon les espèces. Annales de Zoologie-Ecologie Animale 6, 431-441.

Shah, B.H., ZethNer, O., Gul, H. \& Chaudhry, M.I. (1979) Control experiments using Agrotis segetum granulosis virus against Agrotis ipsilon (Lep.: Noctuidae) on tobacco seedlings in northern Pakistan. Entomophaga 24, $393-401$

SHAPIRo, M. (1982) In vivo mass production of insect viruses for use as pesticides, in Microbial and Viral Pesticides (Kurstak, E., Ed.) Marcel Dekker, New York, pp. 463-492. 
Sherlock, P.L. (1983) The natural incidence of disease in the cutworm Agrotis segetum in England and Wales. Annals of Applied Biology 102, 49-56.

Wigley, P.J. (1980) Counting micro-organisms, in Microbial Control of Insect Pests, Bulletin 228 (KaLmakofF, J. \& Longworth, J.F. Eds) New Zealand Dept. of Scientific and Industrial Research, Auckland, New Zealand, pp. 29-35.

YEARIAN, W.C. \& YoUNG, S.Y. (1982) Control of insect pests of agricultural importance by viral insecticides, in Microbial and Viral Pesticides (Kurstak, E. Ed.) Marcel Dekker, New York, pp. 387-423.

ZETHNER, O. (1977) Losses caused by cutworms (Agrotis segetum Schiff.) and approaches to their control in Denmark. Proceedings of the 1977 British Crop Protection Conference-Pests and Disease, British Crop Protection Council, Farnham, UK, pp. 271-277.

ZethNer, O. (1980) Control of Agrotis segetum (Lep.: Noctuidae) root crops by granulosis virus. Entomophaga $25,27-36$.

Zethner, O. \& OGAARD, L. (1982). Studies on the specificity of Agrotis segetum granulosis virus fed to larvae of 17 species of noctuoids. Tidsskrift for Planteavl 86, 471-475.

Zethner, O., Khan, B.M., Chaudhry, M.I., Bolet, B., Khan, S., Khan, H.-U., Gul. H., Ogaard, L., Zaman, M. \& NaWAZ, G. (1987) Agrotis segetum granulosis virus as a control agent against field populations of Agrotis ipsilon and A. segetum (Lep.: Noctuidae) on tobacco, okra, potato and sugar beet in Northern Pakistan. Entomophaga, 32, 449-455. 